\title{
Biochemical Study of Recombinant PcrA from Staphylococcus aureus for the Development of Screening Assays
}

\author{
Sandy Dubaele, Christophe Martin, Jacqueline Bohn and Patrick Chène* \\ Novartis Institutes for BioMedical Research, Oncology Research, CH-4002 Basel, Switzerland
}

Received 12 April 2006, Accepted 6 July 2006

\begin{abstract}
Helicases are ubiquitous enzymes, which utilize the energy liberated during nucleotide triphosphate hydrolysis to separate double-stranded nucleic acids into single strands. These enzymes are very attractive targets for the development of new antibacterial compounds. The PcrA DNA helicase from Staphylococcus aureus is a good candidate for drug discovery. This enzyme is unique in the genome of $S$. aureus and essential for this bacterium. Furthermore, it has recently been published that it is possible to identify inhibitors of DNA helicases such as PcrA. In this report, we study the properties of recombinant PcrA from S. aureus purified from Escherichia coli to develop ATPase and helicase assays to screen for inhibitors.
\end{abstract}

Keywords: ATPase assay, Helicase assay, PcrA, Screening, Staphylococcus aureus

\section{Introduction}

Staphylococci are gram-positive bacteria, which belong to the Bacillaceae family (phylum: Firmicutes). Although more than twenty species of Staphylococcus are described, few of them are significantly associated with human diseases: $S$. saprophyticus (urinary tract infections), $S$. epidermidis (nocosomial infections) and $S$. aureus (Todd, 2005). The later colonizes mainly the nasal passages but is also found in other tissues such as the skin. This bacterium lives completely harmlessly on tissues of about one third of normal healthy people. However, it can cause infections if it enters the body for example via cut or abrasion, being one of the major causes of hospital-acquired infections. $S$. aureus can also induce food poisoning because some strains produce enterotoxins (Le Loir et al., 2003).

$S$. aureus infections were successfully treated with penicillin

*To whom correspondence should be addressed.

Tel: 41616962050; Fax: 41616963835

E-mail: patrick_chene@yahoo.com but drug resistance has developed very fast and new drugs, such as methicillin, were discovered. Today various $S$. aureus strains are resistant to methicillin (Livermore, 2004) and for the treatment of these infections, vancomycin is the only available effective drug. However, strains with some resistance to this antibiotic have already been reported (Chang et al., 2003). Various new antimicrobial agents are being developed (Cooke, 2004) but their efficacy needs to be demonstrated. Since the emergence of new bacterial resistance is a recurrent problem in the treatment of infectious diseases, the search for new drug targets to fight $S$. aureus is becoming very important (Garcia-Lara et al., 2005).

Gene products that are essential for the growth of bacteria are attractive drug targets because their specific inhibition should lead to the death of the targeted bacteria. A systematic disruption of $S$. aureus genes using conditional phenotypes generated by antisense RNA led to the identification of PcrA (amongst other genes) as critical for the survival of this bacterium (Ji et al., 2001), confirming earlier data (Iordanescu, 1993a). We have also recently shown that it is possible to identify low molecular weight inhibitors of a DNA helicase similar to PcrA (Dubaele et al., 2006). Therefore, in addition to be critical for $S$. aureus growth, PcrA might be a "druggable" target.

PcrA, which is present as a single copy in the S.aureus genome (Kuroda et al., 2001; Baba et al., 2002; Holden et al., 2004; Gill et al., 2005), is required for the replication of rolling circle-replicating plasmids in $S$. aureus (Iordanescu, 1993a; Iordanescu, 1993b; Chang et al., 2002). It may regulate the replication of the pT181 plasmid interacting with the replication initiator protein RepC (Iordanescu, 1993a; Chang et al., 2002). PcrA from $S$. aureus has recently been cloned and purified (Chang et al., 2002) and shows both ATPase and helicase activity in vitro (Anand and Khan, 2004). These initial data suggest that it might be possible to develop assays that could be used to screen for inhibitors of this enzyme.

In this report we study the kinetic properties of PcrA from $S$. aureus to establish assays adapted for inhibitor screening. 


\section{Materials and Methods}

Cloning of the PcrA gene. The PcrA gene was amplified by polymerase chain reaction (Expand High Fidelity PLUS PCR System, Roche) using as template the Lambda ZAP II premade library established from $S$. aureus strain RN450 (Stratagene). The primers used were: 5'-CTCTGCTCGAGATGAATGCGTTATTAA ATCATATGAATACAGAGCAAAGTG (XhoI restriction site underlined) and CTCTGGGATCCTTAATCCTCCTTTTTTTCAA TTGGTGCAAATTGCGC (BamHI restriction site underlined). PCR conditions were: $\left(95^{\circ} \mathrm{C} 2 \mathrm{~min}\right) \times 1-\left(95^{\circ} \mathrm{C} 50 \mathrm{~s}, 55^{\circ} \mathrm{C} 50 \mathrm{~s}\right.$ $\left.68^{\circ} \mathrm{C} 4 \mathrm{~min}\right) \times 25\left(68^{\circ} \mathrm{C} 10 \mathrm{~min}\right) \times 1$. The amplified gene was introduced at $\mathrm{XhoI}$ and $\mathrm{Bam} \mathrm{HI}$ restriction sites of a $\mathrm{pET}-14 \mathrm{~b}$ vector (Novagen). The entire coding sequence was verified by double stranded sequencing (Solvias). Site-directed mutagenesis of the PcrA gene was performed by PCR using the QuikChange XL sitedirected mutagenesis kit (Stratagene) according to manufacturer's instructions. The mutated state of the cDNA constructs was confirmed by double stranded sequencing (Solvias).

Expression and purification of the His-tagged PcrA proteins in E. coli. Escherichia coli BL21(DE3)pLysS cells (Stratagene) were transformed with the plasmids encoding wild type or mutated PcrA. Individual colonies were selected on ampicillin LB agar plates. A single colony was used to inoculate a $20 \mathrm{ml}$ pre-culture of Luria broth containing $100 \mu \mathrm{g} / \mathrm{ml}$ ampicillin, $10 \mu \mathrm{g} / \mathrm{ml}$ chloramphenicol (to maintain pLysS) and the pre-culture was grown overnight with shaking at $37^{\circ} \mathrm{C} .2 \mathrm{ml}$ of pre-culture was used to inoculate a $500 \mathrm{ml}$ culture of Luria broth media containing $100 \mu \mathrm{g} / \mathrm{ml}$ ampicillin. The culture was grown with shaking at $37^{\circ} \mathrm{C}$ until the absorbance at 595 $\mathrm{nm}$ reached 0.7 and was induced with $1 \mathrm{mM}$ isopropyl $\beta$-D-1 thiogalactopyranoside (IPTG). Growth was continued for $3 \mathrm{~h}$ at $25^{\circ} \mathrm{C}$, cells were then harvested by centrifugation at $3,500 \mathrm{~g}$ for 15 min at $4^{\circ} \mathrm{C}$, snap frozen in liquid nitrogen and stored at $-80^{\circ} \mathrm{C}$.

The cell pellets were resuspended in ice cold buffer A $(50 \mathrm{mM}$ Tris $\cdot \mathrm{HCl} \mathrm{pH} 7.9,0.5 \mathrm{M} \mathrm{NaCl}, 20 \mathrm{mM}$ imidazole, $0.1 \% \mathrm{NP}-40$, $10 \mathrm{mM}$ 2-mercaptoethanol, $1 \mathrm{mM}$ phenylmethylsulfonyl fluoride, 1 Protease Inhibitor Cocktail Complete, Mini, EDTA-free (Roche) tablet $/ 10 \mathrm{ml}$ buffer). Lysozyme diluted at $1 \mathrm{mg} / \mathrm{ml}$ in buffer A was added and incubated for $15 \mathrm{~min}$ on ice with regular mixing) and the cells were lysed in a French press at 1,000 psi. After centrifugation at $13,000 \mathrm{~g}$ for $15 \mathrm{~min}$ at $4^{\circ} \mathrm{C}$, the soluble fraction was loaded onto a $1 \mathrm{ml}$ Hitrap Nickel column (Amersham) pre-equilibrated at $4^{\circ} \mathrm{C}$ with buffer A. The column was washed with $100 \mathrm{mM}$ imidazole and the bound fraction eluted with $300 \mathrm{mM}$ imidazole. $5 \mathrm{mM}$ ethylenediaminetetraacetic acid (EDTA) were added to the eluted fraction and the solution was loaded at $4^{\circ} \mathrm{C}$ onto a $5 \mathrm{ml}$ HiTrap desalting column (Amersham) pre-equilibrated with storage buffer (50 mM Tris $\cdot \mathrm{HCl}$ pH 7.9, $0.5 \mathrm{M} \mathrm{NaCl}, 0.1 \% \mathrm{NP}-40,10 \mathrm{mM} 2-$ mercaptoethanol). The purified proteins were flash frozen in liquid nitrogen and stored in aliquots at $-80^{\circ} \mathrm{C}$. The protein concentration was determined using the Bio-Rad protein assay (Bio-Rad). The purity of the different proteins was estimated from polyacrylamide gels stained with Coomassie blue.

ATPase assay. ATP hydrolysis was monitored by measuring the production of inorganic phosphate using acidic molybdate and malachite green (Lanzetta et al., 1979). A standard curve made with inorganic phosphate was used to determine the amount of inorganic phosphate produced during the reaction and to ensure that the measurements were made in the linear part of the assay. PcrA proteins $(12 \mathrm{nM})$ were pre-incubated for $5 \mathrm{~min}$ at $37^{\circ} \mathrm{C}$ in $90 \mu \mathrm{l}$ ATPase buffer $(50 \mathrm{mM}$ Tris $\cdot \mathrm{HCl} \mathrm{pH} 7.5,2 \mathrm{mM} \mathrm{MgCl}, 25 \mathrm{mM}$ $\mathrm{KCl}, 1 \mathrm{mM}$ EDTA, $10 \%$ glycerol) containing $10 \mu \mathrm{M} \mathrm{dT}_{25}$ (HPLC purified, Microsynth, Switzerland). The reaction was started by addition of $10 \mu \mathrm{l}$ of ATP (Sigma) and conducted for $10 \mathrm{~min}$ at $37^{\circ} \mathrm{C}$. The reaction mixture $(80 \mu \mathrm{l})$ was transferred into $200 \mu \mathrm{l}$ molybdate/malachite green solution and the absorbance was immediately read at $630 \mathrm{~nm}\left(\mathrm{OD}_{630}\right)$. Kinetic parameters were determined from the measurements of the initial rates (after $10 \mathrm{~min}$ reaction) at different ATP concentrations. For each ATP concentration, the $\mathrm{OD}_{630}$ values measured in the absence of enzyme were subtracted from the corresponding values obtained in the presence of enzyme. The data were analyzed with GraFit (Erithacus Software).

Helicase assay. The helicase unwinding activity was followed by a time-resolved fluorescence quench helicase assay (TR-FQA, Perkin Elmer). Various concentrations of helicase were incubated at $37^{\circ} \mathrm{C}$ (final volume $20 \mu \mathrm{l})$ in helicase buffer $(50 \mathrm{mM}$ Tris $\cdot \mathrm{HCl} \mathrm{pH} 8.5$, $2 \mathrm{mM} \mathrm{MgCl}_{2}, 25 \mathrm{mM} \mathrm{KCl}, 1 \mathrm{mM}$ EDTA, $10 \%$ glycerol, $0.01 \%$ Triton X-100) containing $1 \mathrm{mM}$ ATP, $4 \mathrm{nM}$ helicase substrate (44mer), and $10 \mathrm{nM}$ of the helicase capture strand (26-mer). Strandseparation was monitored by reading the fluorescence at 615 , every 30 secondes (EnVision, Perkin Elmer; top Mirror LANCE/Delfia; Excitation filter: UV (TRF) 340; Emission filter: Europium 615; measurement height $(\mathrm{mm})$ : 6.5 ; delay $(\mu \mathrm{s})$ : 60; window time $(\mu \mathrm{s})$ : 100; number of flashes: 100).

Alternatively, unwinding activity was analyzed using the same dsDNA template in a gel-based radiometric helicase assay. The 44mer strand was radiolabeled with $\gamma\left[{ }^{32} \mathrm{P}\right]-\mathrm{ATP}$ (Amersham Biosciences Redivue $10 \mathrm{mCi} / \mathrm{ml}$ ) on its 5 '-end using T4 polynucleotide kinase (New England Biolabs). Free $\gamma\left[{ }^{32} \mathrm{P}\right]-A T P$ was removed by filtration onto MicroSpin G-25 columns (Amersham Biosciences). Time course helicase reactions were performed at $37^{\circ} \mathrm{C}$ in helicase buffer. The reactions were stopped by adding stop buffer ( $80 \mathrm{mM}$ EDTA, $0.8 \%$ w/v SDS, 35\% v/v glycerol, $0.2 \%$ w/v bromophenol blue). Displaced oligonucleotide was separated from annealed oligonucleotide by $2 \mathrm{~h} 30$ mins electrophoresis onto a homemade $14 \%$ non-denaturing polyacrylamide gel at constant voltage $(170 \mathrm{~V})$. Gels were dried and analyzed by autoradiography.

\section{Results and Discussion}

Cloning and purification of $P$ cr $A$ from $S$. aureus strain RN450. The PcrA gene was cloned from $S$. aureus strain RN450 library. Since the amino acid sequence of this protein was not found in protein database, the primary sequence of the cloned protein was compared to the one of PcrA proteins from other strains (Mu50 (P64318), N315 (P64319), SA20 (Q53727), MW2 (Q8NVT1) - SwissProt accession numbers are in brackets) using T-Coffee (Notredame et al., 2000). PcrA strain RN450 is identical to PcrA strain MW2 (data not shown) and has only small differences compared to other strains. In strains RN450 and MW2 the sequence 665RTTS 
$(\mathrm{kDa})$ wt Thr34Ala

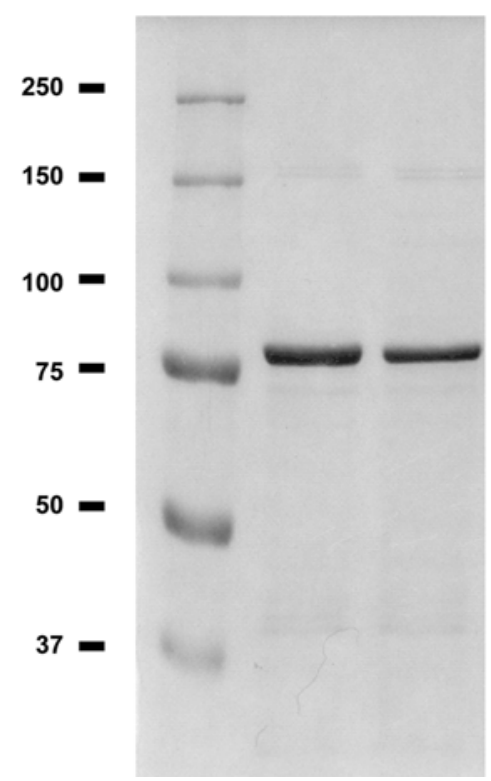

Fig. 1. Purity of the protein preparations. wt and Thr34Ala were purified as described under "Materials and Methods". The two proteins $(5 \mathrm{mg})$ were heat denatured and loaded onto a SDSPAGE. The gel was stained with Coomassie Blue. Protein standards with the indicated molecular weights are shown to the left of the gel.

TKKQVLS675 is present while the sequence is 665R-STKKQVLS673 in strain SA20 and 665RTTSTKKQVSS675 in strains Mu50 and N315 (deletions are represented by dashes, non-conserved residues are underlined).

PcrA was expressed in E. coli as a soluble N-terminal $\mathrm{His}_{6}-$ tagged protein allowing its direct purification by Immobilized Metal Affinity Chromatography (IMAC) with a $\mathrm{Ni}^{2+}$ column. To further improve the purity of the protein preparations, we tried to add a second step (e.g., ion exchanger or heparin column) in the purification scheme. However, most of the IMAC purified PcrA precipitated during the desalting step (gel filtration or dialysis), used to reduce the high ionic strength $(500 \mathrm{mM} \mathrm{NaCl})$ of the IMAC buffer. We also observed that the ATPase activity of the IMAC purified proteins was enhanced in the presence of EDTA suggesting that a cation (most probably $\mathrm{Ni}^{2+}$ from the IMAC column) poisoned a fraction of the PcrA protein. EDTA $(5 \mathrm{mM})$ was added to the IMAC purified protein fractions and the buffer was exchanged by gel filtration (keeping a high ionic strength to avoid precipitation). In such conditions the purity of the protein preparations was higher than $90 \%$ (Fig. 1).

To generate an ATPase inactive PcrA protein, the threonine residue of motif I (Walker A), AGAGSGKT, was mutated to alanine (Thr34Ala). This residue is important for the interaction with the nucleotide (ATP) and the cofactor $\left(\mathrm{Mg}^{2+}\right)$ (Soultanas et al., 1999). Thr34Ala was expressed as a soluble protein and purified with the same purification protocol as the wild-type (wt) protein. The purity of the Thr34Ala mutant is similar to wt (Fig. 1).

Optimization of the ATPase assay. It has been shown that the ATPase activity of S. aureus and Bacillus anthracis PcrA is stimulated in the presence of nucleic acid substrates (Chang et al., 2002; Naqvi et al., 2003; Anand and Khan, 204). Several of these activating nucleic acids have complicated structures and may not be easy to use in high throughput assays. Bird et al. have published that the ATPase activity of PcrA from Bacillus stearothermophillus can be stimulated in the presence of short dT oligonucleotides (Bird et al., 1998). In agreement with these data we found that $\mathrm{dT}_{25}$ stimulates the ATPase activity of PcrA from $S$. aureus. The concentration of the activating $\mathrm{dT}_{25}$ was varied in the assay and the rate of ATP hydrolysis determined (Fig. 2A). In the absence of ssDNA, the enzyme has no ATPase activity. Maximal activity is achieved when $10 \mu \mathrm{M}$ oligonucleotide are present in the assay but a slight inhibition of ATP hydrolysis is observed at higher concentrations. Non-linear regression analysis of these data with the equation $A=[D] \cdot A_{\max } /\left(K_{d}+[D]\right)\left(A\right.$ and $A_{\max }$ ATPase and maximal ATPase activity; [D] $\mathrm{dT}_{25}$ concentration; $\mathrm{K}_{\mathrm{d}}$ dissociation constant for $\mathrm{dT}_{25}$ ) gives a $\mathrm{K}_{\mathrm{d}}$ value of $865 \mathrm{nM}$ $\pm 217(\mathrm{n}=3)$ for $\mathrm{dT}_{25}$.

The influence of divalent cations on PcrA activity was investigated at saturating concentration of ATP and $\mathrm{dT}_{25}$ (Fig. 2B). In the absence of divalent cation, the enzyme has no ATPase activity and $\mathrm{Mg}^{2+}$ is the best metal cofactor for PcrA activity. Two other cations $-\mathrm{Mn}^{2+}$ and $\mathrm{Ca}^{2+}$ - stimulate the ATPase activity to a lower extent than $\mathrm{Mg}^{2+}$. To identify the optimal concentration of $\mathrm{Mg}^{2+}$ in the assay, the ATPase activity was measured in the presence of various concentrations of this cation (Fig. 2C). A maximal activity was observed for $2 \mathrm{mM}$ $\mathrm{Mg}^{2+}$. At high $\mathrm{Mg}^{2+}$ concentrations (above $3 \mathrm{mM}$ ), a slight inhibition of the ATPase activity is observed.

The temperature at which the highest rate of ATP hydrolysis is obtained was determined (Fig. 2D). Not surprisingly for a protein from a bacterium that colonizes human, maximum ATP hydrolysis was observed around $37^{\circ} \mathrm{C}$. It can be noticed that maximal activity is observed in a rather narrow temperature window.

The effect of the ionic strength on the ATPase activity of PcrA was determined varying the concentration of salt $(\mathrm{KCl})$ in the assay (Fig. 2E). Ionic strength has an important effect on PcrA activity. The ATPase activity is maximal at low salt concentrations $(0-50 \mathrm{mM})$ and decreases rapidly with increasing ionic strength. This result is surprising since we observed that PcrA precipitates during purification at low ionic strength (see above). One possibility to explain these observations is that PcrA aggregates at high concentrations (purification) but not at lower concentrations (assay). Alternatively, since the assay is carried out in the presence of an excess of $\mathrm{dT}_{25}$, the formation of PcrA-dT 25 complexes may protect the enzyme from aggregating at low ionic strength.

$\mathrm{pH}$ influences to a great extent PcrA activity (Fig. 2F) and 

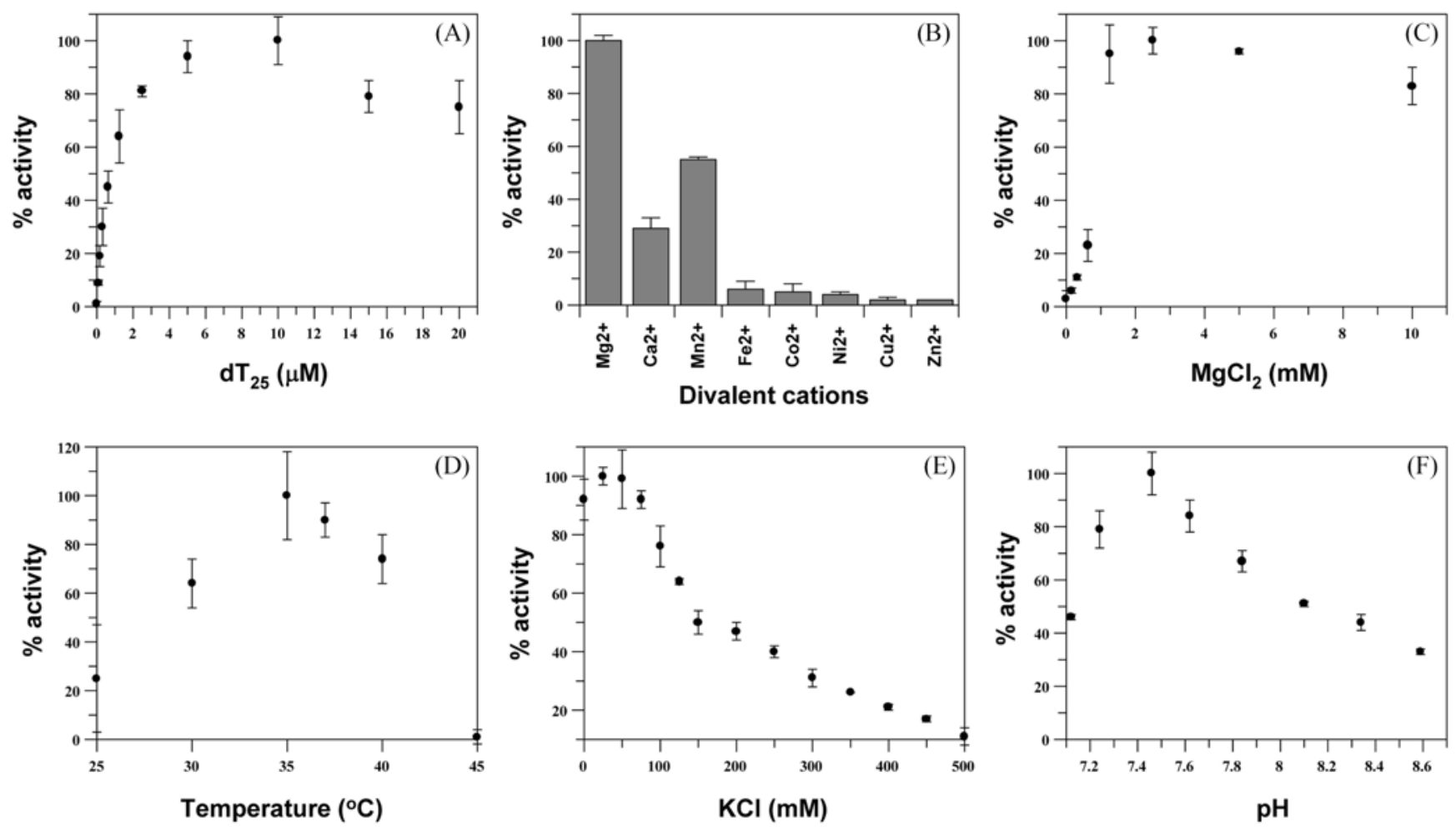

Fig. 2. Optimization of the ATPase assay. The ATPase activity of wt PcrA was measured with the Malachite Green assay in the presence of saturating ATP concentrations $(1 \mathrm{mM})$. Several parameters $-\mathrm{dT}_{25}$ concentration $(\mathrm{A})$, nature of the divalent cation $(\mathrm{B}), \mathrm{Mg}^{2+}$ concentration $(\mathrm{C})$, temperature $(\mathrm{D})$, ionic strength $(\mathrm{E})$ and $\mathrm{pH}(\mathrm{F})$ - were varied in the assay conditions to obtain a maximal ATPase activity for PcrA.

the $\mathrm{pH}$ region where a maximal rate for ATP hydrolysis is observed is narrow and centered around $\mathrm{pH} 7.5$.

To ensure that the ATPase activity detected in the optimal conditions determined above is PcrA specific, both the wt and the Thr34Ala proteins were incubated in the presence of saturating concentration of ATP $(1 \mathrm{mM})$ and $\mathrm{dT}_{25}(10 \mu \mathrm{M})$ and the amount of inorganic phosphate released measured. The results presented on figure $3 \mathrm{~A}$ show that ATP hydrolysis is observed only in the presence of the wt enzyme demonstrating that the ATPase activity measured in the assay is PcrA dependent.

\section{Determination of the kinetic parameters for the ATPase} activity of PcrA. The kinetic parameters of PcrA from $S$. aureus were measured. To determine steady state conditions, PcrA was incubated in the presence of the lowest $(15 \mu \mathrm{M})$ and highest $(1,000 \mu \mathrm{M})$ ATP concentrations used for kinetic parameters measurements and the amount of released inorganic phosphate was measured at different time points. In such conditions the reaction is linear up to $15-20 \mathrm{~min}$ after the addition of ATP (Fig. 3B). PcrA was then incubated for 10 min in the presence of different ATP concentrations and the rate of ATP hydrolysis determined. The plot of initial rate of ATP hydrolysis versus ATP concentration shows that $S$. aureus PcrA mediated ATP hydrolysis follows the MichaelisMenten equation (Fig. 3C) as already observed for another PcrA (Bird et al., 1998). Non-linear regression analysis of these data using the equation: $\mathrm{v}=\mathrm{k}_{\mathrm{cat}} \cdot\left[\mathrm{E}_{\mathrm{o}}\right] \cdot[\mathrm{S}] /\left(\mathrm{K}_{\mathrm{m}}+[\mathrm{S}]\right)$ ( $\mathrm{k}_{\text {cat }}$ catalytic constant; [ $\mathrm{E}_{\mathrm{o}}$ ] enzyme concentration; [S] ATP concentration; $\mathrm{K}_{\mathrm{m}}$ Michaelis constant for ATP) gives $\mathrm{K}_{\mathrm{m}}$ and $\mathrm{k}_{\text {cat }}$ values of $63 \mathrm{mM} \pm 5(\mathrm{n}=5)$ and $6 \mathrm{~s}^{-1} \pm 1(\mathrm{n}=5)$, respectively. It is important to note that $\mathrm{k}_{\text {cat }}$ was determined using the following formula $\mathrm{k}_{\text {cat }}=\mathrm{V}_{\max } /\left[\mathrm{E}_{\mathrm{o}}\right]\left(\mathrm{V}_{\max }\right.$ maximal rate of ATP hydrolysis). This value therefore corresponds to an apparent $\mathrm{k}_{\text {cat }}$ because it was assumed that all the PcrA protein present in the assay is active. The published kinetic parameters for PcrA from B. stearothermophilus $-\mathrm{K}_{\mathrm{m}}=56 \mu \mathrm{M}$ and $\mathrm{k}_{\mathrm{cat}}=11 \mathrm{~s}^{-1}$ are very similar to the ones determined here for PcrA from $S$. aureus (Dillingham et al., 1999).

Optimization of the helicase assay. To determine the polarity of the purified PcrA protein, its unwinding activity was measured in a gel-based radiometric helicase assay. In agreement with Anand and Khan (Anand and Khan, 2004), we found that PcrA from $S$. aureus has a high $3^{\prime} \rightarrow 5^{\prime}$ helicase activity and a weaker $5^{\prime} \rightarrow 3^{\prime}$ activity (Fig. 4A). To exclude the possibility that the observed helicase activities were due to the presence of protein contaminants, the unwinding activity of the Thr34Ala protein was measured. In similar experimental conditions, no helicase activity was observed with Thr34Ala (Fig. 4B) revealing that both unwinding activities are PcrA specific.

Gel-based radiometric helicase assays are very useful to 
(A)

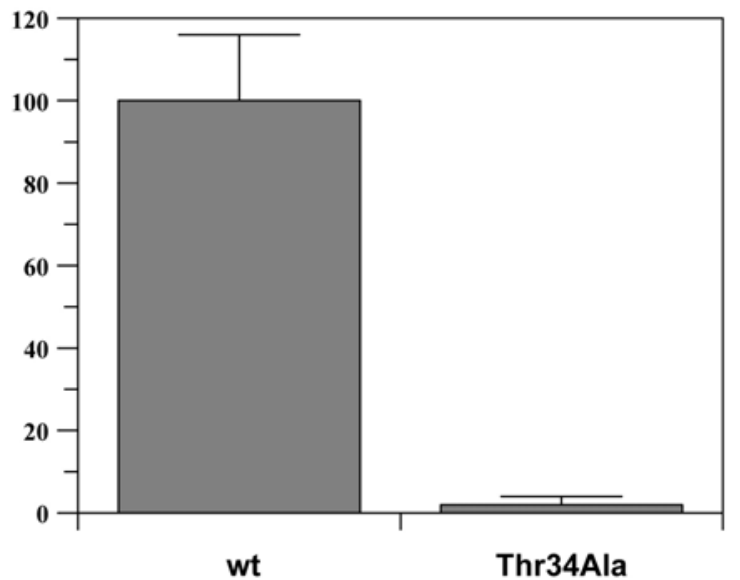

(B)

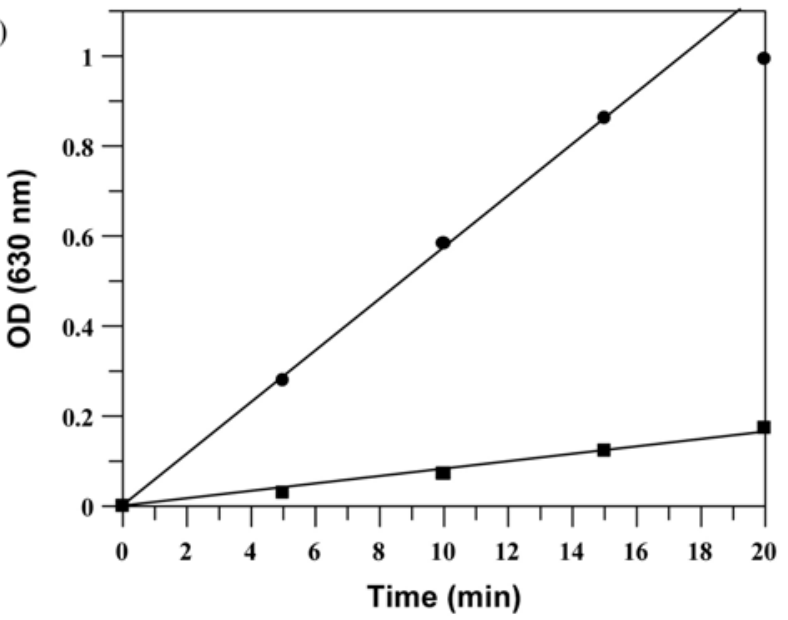

(C)

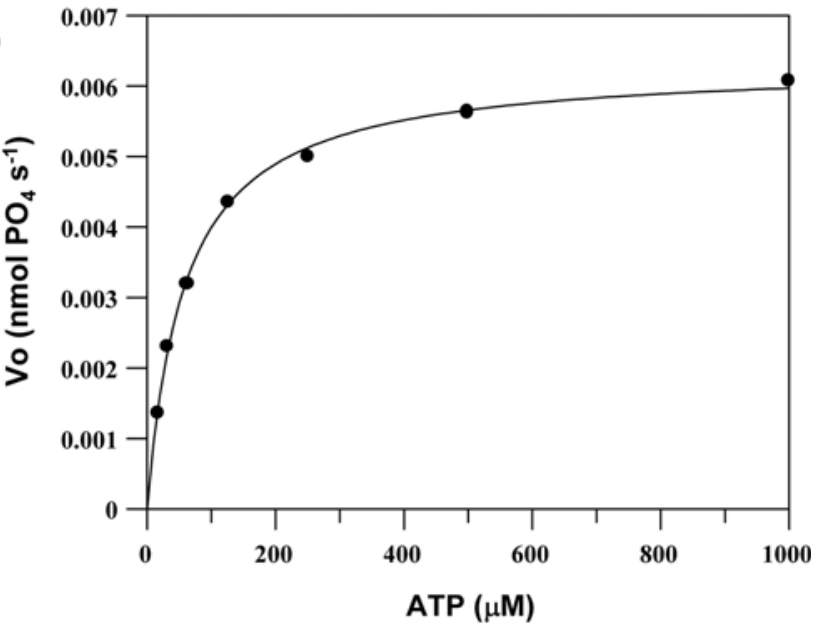

Fig. 3. Kinetic parameters of PcrA from $S$. aureus. (A) The ATPase activity of the wt and Thr34Ala proteins was measured in the presence of saturating concentration of ATP with the Malachite Green assay. (B) Initial rate measurement. The change in optical density at $630 \mathrm{~nm}\left(\mathrm{OD}_{630}\right)$ was measured for to ATP concentrations - $15 \mathrm{mM}(\boldsymbol{\square})$ and $1 \mathrm{mM}(\boldsymbol{O})$ - at different time points in the Malachite Green assay. The lines indicate the linear correlation between $\mathrm{OD}_{630}$ and time during the first 15 min to 20 min of the assay. (C) A representative plot of measured initial rates of ATP hydrolysis versus ATP concentration in the presence of saturating concentration of $\mathrm{dT}_{25}$. The data have been fitted with the Michaelis-Menten equation.

study the properties of an enzyme but their low throughput prevents screening of large compound libraries. We therefore tested PcrA helicase activity in a homogeneous time-resolved fluorescence quenching assay (Karvinen et al., 2004) that can be adapted to high throughput screen. In this assay, the helicase substrate contains two complementary oligonucleotide strands, one labeled with the highly fluorescent europium (Eu) chelate (44-mer) and the second labeled with a quencher of europium fluorescence (QSY 7) (26-mer). Upon annealing of the two complementary strands, the fluorescence of the Euchelate is quenched due to energy transfer between the labels. Upon addition of the helicase, the two strands are separated and the recovery of the $\mathrm{Eu}$ fluorescence is measured. To prevent re-annealing of the quencher- and Eu-strands, a capture strand (26-mer) complementary to the quencher strand is present in the assay (Karvinen et al., 2004).
The helicase activity of PcrA was measured in this assay using different concentrations of enzymes (Fig. 4C). The experimental data show that increasing the concentration of enzyme in the assay enhances the rate of DNA unwinding. However the linear dependence of enzyme activity as a function of incubation time is affected. At higher PcrA concentrations linearity is kept for only short incubation times. In experimental conditions where 20 or $40 \mathrm{nM}$ of PcrA are present in the assay, the reaction can be monitored in the linear range of the assay (up to $10 \mathrm{~min}$ ) keeping a good dynamic range (signal to noise ratio between 5 and 20) for incubation times comprised between 5 to $10 \mathrm{~min}$ (Fig. 4D).

Since the residues involved in ATP and nucleic acid binding are not the same, the optimal $\mathrm{pH}\left(\mathrm{pK}_{\mathrm{a}}\right.$ of the contact residues) and/or the ionic strength (lipophylicity of the contact residues) identified for the ATPase activity might be different 
(A)

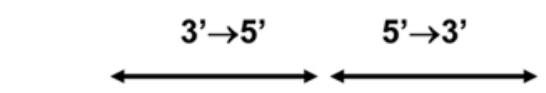

$(-) \quad \Delta \quad 15 \quad 30 \quad 601201530 \quad 60120(\min )$

dsDNA

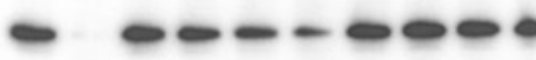

ssDNA

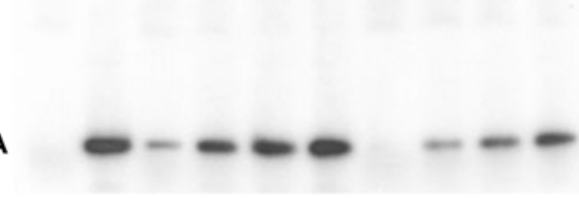

(B)

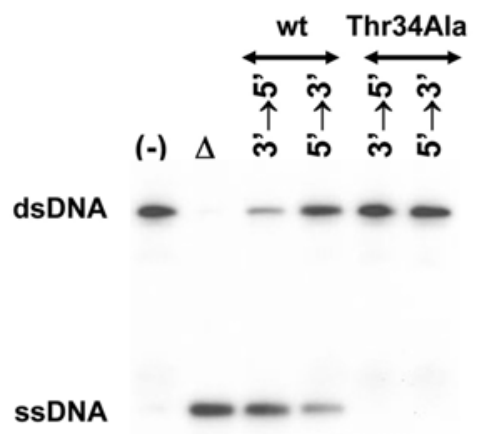

(C)

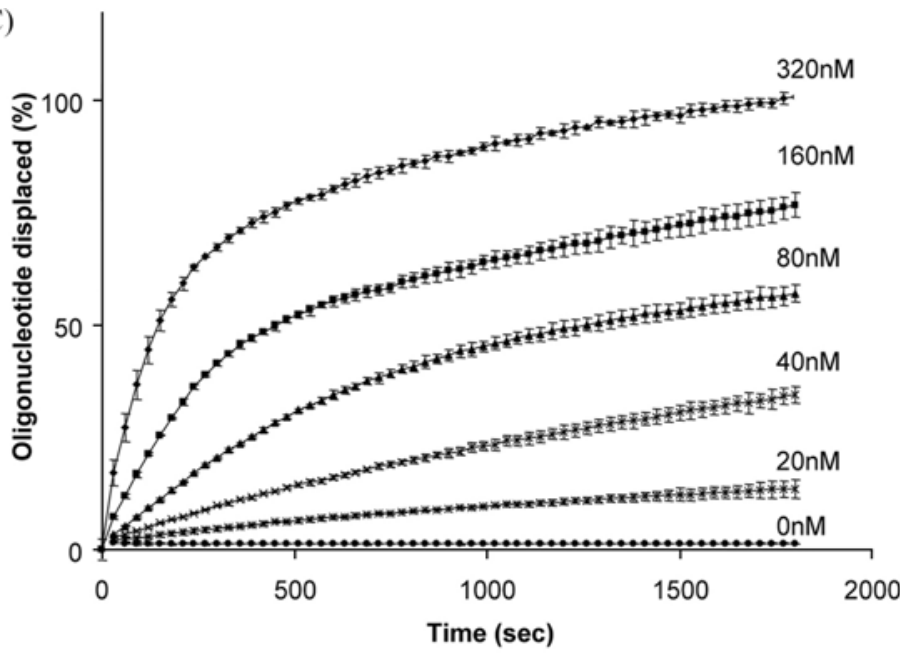

(D)

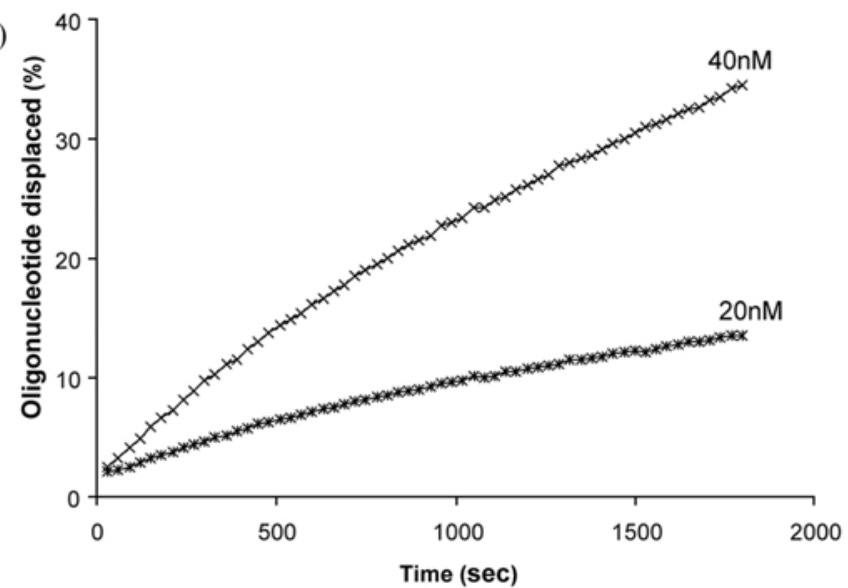

Fig. 4. Helicase activity of PcrA from $S$. aureus. (A) The 3'-5' and 5'-3' helicase activities of wt PcrA have been measured in a gelbased radiometric helicase assay. The radiolabelled strand displaced during the reaction was separated from the "annealed probe" by non-denaturating polyacrylamide gel electrophoresis. The gels were dried and autoradiographed. Delta represents the heat denatured probe. (-) reaction without enzyme. (B) The helicase activities of the wt and Thr34Ala mutant were compared in the gel-based radiometric helicase assay. (C) The strand displacement activity of the different enzymes was measured in a time-resolved fluorescence quench helicase assay. The amount of oligonucleotide displaced was measured every $30 \mathrm{~s}$ during 30 min and in the presence of different concentrations of wt PcrA. (D) Linear dependence between the amount of oligonucleotide displaced and the time was measured in the presence of 20 and $40 \mathrm{nM}$ wt PcrA.

for the helicase activity. The helicase activity of PcrA was measured at different $\mathrm{pH}$ and salt conditions in the timeresolved fluorescence quenching assay (Fig. 5A, B). Helicase activity follows exactly the same $\mathrm{pH}$ and salt concentration dependency than the ATPase activity. $\mathrm{pH}$ and salt conditions did not significantly affect the europium fluorescence within our experimental conditions (data not shown). In this respect, PcrA behaves differently than the hepatitis C virus NS3 helicase. For this enzyme, $\mathrm{pH}$ and salt concentration influence the ATPase and helicase activities in a different manner (Wardell et al., 1999).

To further evaluate both the ATPase and helicase assays, additional experiments were carried out. The influence of dimethylsulfoxide (DMSO), an organic solvent commonly used to solubilize synthetic small molecules, was tested in the assays (Fig. 6A). The experimental data show that DMSO up to $4 \%$ does not affect both assays. The stability of the recombinant PcrA protein on ice was also investigated. The enzyme does not significantly loose its activity when stored on ice up to $120 \mathrm{~min}$ (data not shown). To demonstrate that inhibitors of PcrA can be identified with both assays, the ATPase and helicase activities of the enzyme were measured in the presence of various concentrations of a non-hydrolyzable analog of ATP, ATP $\gamma$ S. The data presented on Figure $6 \mathrm{~B}$ reveal that ATP $\gamma \mathrm{S}$ inhibits PcrA in a dose dependent manner in both assays. The concentration of $\mathrm{ATP} \gamma \mathrm{S}$ required to inhibit $50 \%$ of the enzymatic activity $\left(\mathrm{IC}_{50}\right)$ is $5.9 \mu \mathrm{M} \pm 0.4$ in the helicase assay and $6.2 \mu \mathrm{M} \pm 0.5$ in the ATPase assay. It is important to note that similar $\mathrm{IC}_{50} \mathrm{~S}$ are measured in both assays. To measure the robustness of the 2 assays the $Z^{\prime}$ - 

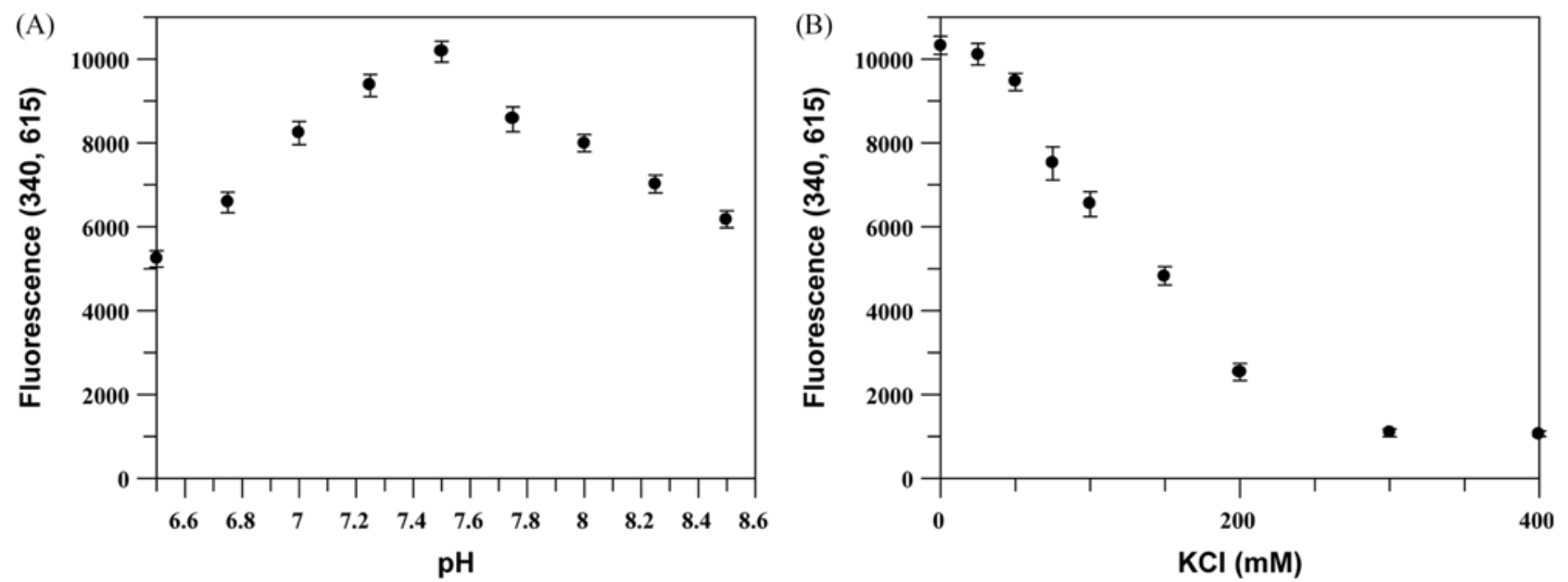

Fig. 5. Influence of $\mathrm{pH}$ and ionic strength on PcrA helicase activity. The helicase activity of PcrA ( $40 \mathrm{nM})$ from $S$. aureus has been measured at different $\mathrm{pH}(\mathrm{A})$ and different salt concentrations (B) in a homogeneous time-resolved fluorescence quenching assay.
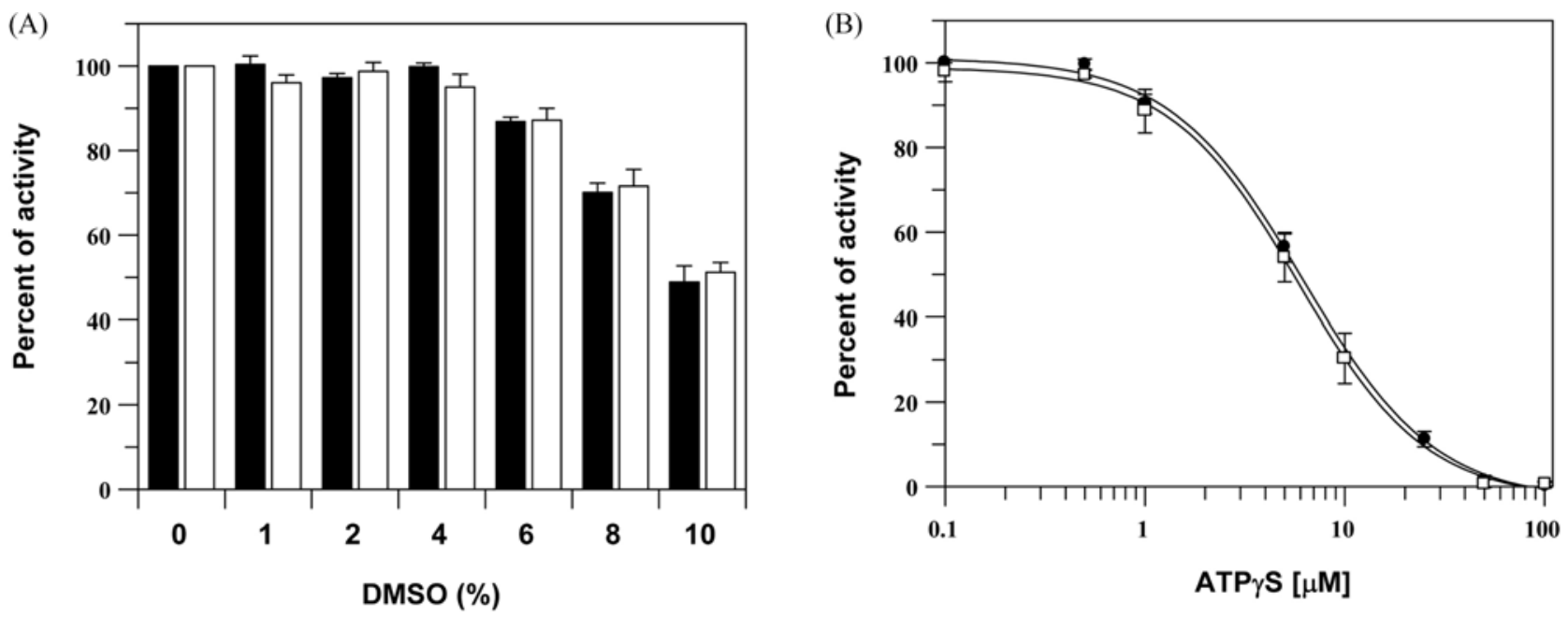

Fig. 6. Influence of DMSO and inhibition of PcrA by ATP $\gamma$ S. (A) The ATPase (black bars) and helicase (white bars) activities were measured $(n=3)$ in the presence of the indicated amount of DMSO. (B) The ATPase (closed circles) and helicase (open squares) activities of PcrA were measured in the presence of different ATP $\gamma \mathrm{S}$ concentrations. The figure represents the average of 3 independent experiments.

factors (Zhang et al., 1999) were calculated. Assays with Z'factor values between 0.5 and 1 have a good dynamic range and a small standard deviation. The $Z$ '-factors are $0.91(\mathrm{n}=10)$, $0.93(n=10), 0.92(n=10)$ and $0.85(n=10)$ for the ATPase and helicase (40 and $20 \mathrm{ng}$ protein) assays, respectively. This indicates that both assays can be used for screening purposes. However, since small volumes $(20 \mu \mathrm{l})$ are used for the helicase assay, this assay should be preferentially used as the primary assay during a screening campaign. The ATPase assay, which uses larger amount of material, could be used as secondary assay to evaluate the hits obtained with the helicase assay.

In summary, we have adapted a colorimetric ATPase assay and a homogeneous time-resolved fluorescence quenching helicase assay that could be used to screen compound libraries in order to identify PcrA inhibitors. Even so a mutation of the recF suppresses the lethality of PcrA deletion in B. subtilis (Petit and Ehrlich, 2002), PcrA remains an attractive drug target because its deletion is lethal in $S$. aureus (Iordanescu, 1993a; Ji et al., 2001) and so far no suppressor has been found for this bacterium. Furthermore the suppressor identified in $B$. subtilis rescues only partially the phenotype induced by $P$ crA deletion (Petit and Ehrlich, 2002). Since the DNA binding site of helicases such as PcrA is attractive for drug discovery (Dubaele et al., 2006), the two assays described in this report could be very useful to identify new antibacterial drugs. Furthermore these assays could be adapted to screen for inhibitors of other helicases. 


\section{References}

Anand, S. P. and Khan, S. A. (2004) Structure-specific DNA binding and bipolar helicase activities of PcrA. Nucleic Acids Res. 32, 3190-3197.

Baba, T., Takeuchi, F., Kuroda, M., Yuzawa, H., Aoki, K., Oguchi, A., Nagai, Y., Iwama, N., Asano, K., Naimi, T., Kuroda, H., Cui, L., Yamamoto, K. and Hiramatsu, K. (2002) Genome and virulence determinants of high virulence community-acquired MRSA. Lancet 359, 1819-1827.

Bird, L. E., Brannigan, J. A., Subramanya, S. H. and Wigley, D. B. (1998) Characterisation of Bacillus stearothermophillus PcrA helicase: evidence against an active rolling mechanism. Nucleic Acid Res. 26, 2686-2693.

Chang, S., Sievert, D. M., Hageman, J. C., Boulton, M. L., Tenover, F. C., Downes, F. P., Shah, S., Rudrik, J. T., Pupp, G. R., Brown, W. J., Cardo, D. and Fridkin, S. K. (2003) Infection with vancomycin-resistant Staphylococcus aureus containing the vanA resistance gene. N. Engl. J. Med. 348, 1342-1347.

Chang, T. L., Naqvi, A., Anand, S. P., Kramer, M. G., Munshi, R. and Khan, S. A. (2002) Biochemical characterization of the Staphylococcus aureus PcrA helicase and its role in plasmid rolling circle replication. J. Biol. Chem. 277, 45880-45886.

Cooke, J. (2004) Infectious diseases - the need for new antibiotics. Hospital Pharmacist 11, 265-268.

Dillingham, M. S., Soultanas, P. and Wigley, D. B. (1999) Sitedirected mutagenesis of motif III in PcrA helicase reveals a role in coupling ATP hydrolysis to strand separation. Nucleic Acids Res. 27, 3310-3317.

Dubaele, S., Jahnke, W., Schoepfer, J., Fuchs, J. and Chene, P. (2006) Inhibition of DNA helicases with DNA-competitive inhibitors. Bioorg. Med. Chem. Lett. 16, 923-927.

Garcia-Lara, J., Masalha, M. and Foster, S. J. (2005) Staphylococcus aureus: the search for novel targets. Drug Disc Today 10, 643651.

Gill, S. R., Fouts, D. E., Archer, G. L., Mongodin, E. F., Deboy, R. T., Ravel, J., Paulsen, I. T., Kolonay, J. F., Brinkac, L., Beanan, M., Dodson, R. J., Daugherty, S. C., Madupu, R., Angiuoli, S. V., Durkin, A. S., Haft, D. H., Vamathevan, J., Khouri, H., Utterback, T., Lee, C., Dimitrov, G., Jiang, L., Qin, H., Weidman, J., Tran, K., Kang, K., Hance, I. R., Nelson, K. E. and Fraser, C. M. (2005) Insights on evolution of virulence and resistance from the complete genome analysis of an early methicillin-resistant Staphylococcus aureus strain and a biofilmproducing methicillin-resistant Staphylococcus epidermidis strain. J. Bacteriol. 187, 2426-2438.

Holden, M. T. G., Feil, E. J., Lindsay, J. A., Peacock, S. J., Day, N. P. J., Enright, M. C., Foster, T. J., Moore, C. E., Hurst, L., Atkin, R., Barron, A., Bason, N., Bentley, S. D., Chillingworth, C., Chillingworth, T., Churcher, C., Clark, L., Corton, C., Cronin, A., Doggett, J., Dowd, L., Feltwell, T., Hance, Z., Harris, B., Hauser, H., Holroyd, S., Jagels, K., James, K. D., Lennard, N., Line, A., Mayes, R., Moule, S., Mungall, K., Ormond, D., Quail, M. A., Rabbinowitsch, E., Rutherford, K., Sanders, M., Sharp, S., Simmonds, M., Stevens, K., Whitehead,
S., Barrell, B. G., Spratt, B. G. and Parkhill, J. (2004) Complete genomes of two clinical Staphylococcus aureus strains: Evidence for the rapid evolution of virulence and drug resistance. Proc. Natl. Acad. Sci. USA 101, 9786-9791.

Iordanescu, S. (1993a) Characterization of the Staphylococcus aureus chromosomal gene PcrA, identified by mutations affecting plasmid pT181 replication. Mol. Gen. Genet. 241, 185-192.

Iordanescu, S. (1993b) Plasmid pT181-linked suppressors of Staphylococcus aureus PcrA3 chromosomal mutation. J. Bacteriol. 175, 3916-3917.

Ji, Y., Zhang, B., Van Horn, S. F., Warren, P., Woodnutt, G., Burnham, M. K. R. and Rosenberg, M. (2001) Identification of critical staphylococcal genes using conditional phenotypes generated by antisense RNA. Science 293, 2266-2269.

Karvinen, J., Laitala, V., Makinen, M. L., Mulari, O., Tamminen, J., Hermonen, J., Hurskainen, P. and Hemmila, I. (2004) Fluorescence quenching-based assays for hydrolyzing enzymes. Application of time-resolved fluorometry in assays for caspase, helicase and phosphatase. Anal. Chem. 76, 1429-1436.

Kuroda, M., Ohta, T., Uchiyama, I., Baba, T., Yuzawa, H., Kobayashi, I., Cui, L., Oguchi, A., Aoki, K., Nagai, Y., Lian, J., Ito, T., Kanamori, M., Matsumaru, H., Maruyama, A., Murakami, H., Hosoyama, A., Mizutani-Ui, Y., Takahashi, N. K., Sawano, T., Inoue, R., Kaito, C., Sekimizu, K., Hirakawa, H., Kuhara, S., Goto, S., Yabuzaki, J., Kanehisa, M., Yamashita, A., Oshima, K., Furuya, K., Yoshino, C., Shiba, T., Hattori, M., Ogasawara, N., Hayashi, H. and Hiramatsu, K. (2001) Whole genome sequencing of meticillin-resistant Staphylococcus aureus. Lancet 357, 1225-1240.

Lanzetta, P. A., Alvarez, L. J., Reinach, P. S. and Candia, O. A. (1979) An improved assay for nanomole amounts of inorganic phosphate. Anal. Biochem. 100, 95-97.

Le Loir, Y., Baron, F. and Gautier, M. (2003) Staphylococcus aureus and food poisoning. Genet. Mol. Res. 2, 63-76.

Livermore, D. M. (2004) The need for new antibiotics. Clin. Microbiol. Infect. 10, 1-9.

Naqvi, A., Tinsley, E. and Khan, S. A. (2003) Purification and characterization of the PcrA helicase of Bacillus anthracis. $J$. Bacteriol. 185, 6633-6639.

Notredame, C., Higgins, D. and Heringa, J. (2000) T-Coffee: A novel method for multiple sequence alignments. J. Mol. Biol. 302, 205-217.

Petit, M. A. and Ehrlich, D. (2002) Essential bacterial helicases that counteract the toxicity of recombination proteins. EMBO J. 21, 3137-3147.

Soultanas, P., Dillingham, M. S., Velankar, S. S. and Wigley, D. B. (1999) DNA binding mediates conformational changes and metal ion coordination in the active site of PcrA helicase. $J$. Mol. Biol. 290, 137-148.

Todd, J. K. (2005) Staphylococcal infections. Pediatr. Rev. 26, 444-450.

Wardell, A. D., Errington, W., Ciaramella, G., Merson, J. and McGarvey, M. J. (1999) Characterization and mutational analysis of the helicase and NTPase activities of hepatitis C virus full-length NS3 protein. J. Gen. Virol. 80, 701-709. 